\title{
FIBRE LENGTH OF FAST- AND SLOW-GROWN BLACK COTTONWOOD
}

\author{
BY R. W. KENNEDY ${ }^{2}$
}

Robert $W$. Kennedy holds a B.S. degree from the State University of New York, College of Forestry and a M.F. degree from the University of British Columbia. He has held summer positions with the Vancouver Laboratory, Forest Products Laboratories of Canada, and was Instructor in the Faculty of Forestry, University of British Columbia, during the 1955-1956 Session. He is currently studying at the School of Forestry, Yale University, for the Ph.D. degree.

\section{ABSTRACT}

The lengths of fibres from fast-and slow-grown black cottonwood trees were measured at comparable heights and ages. Fibre length was found to vary directly and significantly with both growth rate and age from pith. An additional investigation showed that fast-grown sprouts had longer fibres than slow-grown sprouts of equal age collected from the same stump source. The mechanisms regulating fibre length in trees are discussed briefly.

\section{INTRODUCTION}

The factors influencing fibre and tracheid length have previously been studied by several workers. In a variety of species, fibre length has been found to increase with distance from the pith in early years until a more or less constant figure is reached. This fact has recently been reaffirmed by Kaeiser (8) while studying eastern cottonwood (Populus deltoides Bart.). Furthermore, investigations into the variation within annual growth increments have generally revealed a pattern of shorter fibres in the early-wood portions of the rings $(4,7)$.

The evidence correlating growth rate with fibre or tracheid length is contradictory. From a literature review, Spurr and Hyvärinen (9) have concluded that rapid growth is related to long fibres. Australian workers $(1,5)$ have shown an inverse relationship between growth rate and fibre length. This study was undertaken to determine the effect of rate of growth on the fibre length of northern black cottonwood (Populus trichocarpa Torr. and Gray). ${ }^{*}$ Length variations are of some practical interest, since long-fibred pulps are generally preferred in the production of high-strength papers.

\section{Materials and Methods}

Four trees growing on a poor site were selected to represent slow-growth black cottonwood. Two trees from the same general area, but from a better site were chosen as fast-growth trees. Two additional fast-grown trees were taken from a different area, to complete the total of eight trees sampled. Disks

\footnotetext{
${ }^{1}$ Research Note No. 12, Frculty of Forestry, University of British Columbia. Daper accepted for publication July 25, 1956.

2 Instructor, 1955-56 Session, Faculty of Forestry, University of British Columbia.

a The effect of growth rate in Populus hybrids has been investigated by L. P. V. Johnson (Studies on the relation of growth rate to wood quality in Populus hybrids. Can. J. Res. 20: 28-40. 1942). However, fibre length measurement was confounded by sampling rings at different ages from the pith; i.e. the effect of distance from pith on fibre length was not considered.
} 
three inches thick were sawn from each tree at the 4.5-, 18- and 36-foot levels above ground. A representative radius (one-half inch wide) was then sawn from each disk. From these radii the second, fifth, tenth and fifteenth annual increments from the pith were carefully dissected. The age of each breast-height (4.5 ft.) section was determined from the sampled radius, and the average growth rate of each tree in rings per inch was calculated. These values are recorded in Table 1 . Two distinct growth-rate classes were obtained; the slowgrowth trees had from 7.4 to 10.9 rings per inch, whereas the fast-growth material ranged between 2.7 and 4.7 rings per inch.

TABLE 1

Classification of Samples

\begin{tabular}{cccc}
\hline Growth Class & Tree No. & Age at DBH & Rings per Inch \\
\hline Slow & 1 & 38 & 10.9 \\
& 2 & 38 & 7.4 \\
& 3 & 40 & 8.2 \\
& 4 & 36 & 10.7 \\
\hline Fast & 5 & 37 & 3.7 \\
& 6 & 28 & 3.2 \\
& 7 & 46 & 4.7 \\
& 8 & 28 & 2.7 \\
\hline
\end{tabular}

The dissected annual increments were macerated separately by heating in glacial acetic acid and 30 per cent hydrogen peroxide $(1: 1)$ at $100^{\circ} \mathrm{C}$. After delignication was complete, the material was washed with water several times and reduced to fibres by mild shaking. A few grains of brilliant cresyl blue were added to the pulp suspension in order to stain the fibres. A pipette was employed to transfer a small quantity of this suspension to a glass slide. Glycerine was used as the mounting medium. Ten randomly chosen fibres were measured on each slide from images projected on a graduated target (11).

In this study one variable so far remained uncontrolled-that of heredity. Possible fibre length differences between trees could not be attributed entirely to growth factors without first dismissing genetic variability. This was done by selecting additional material in the form of two- and three-year-old stump sprouts. From the base of each of four black cottonwood stumps, five or six straight or only slightly leaning sprouts were selected to provide a good range in diameter. In this way material of different growth rates was obtained from the same parent.

A piece one inch in length was removed from each sprout at a point approximately two inches below the uppermost node. The resulting cylinder thus contained the complete 1955 increment in addition to a small inner core, representing the tip of the growth in 1954 . The latter was removed by dissection, and the radial width of the remaining material (1955 growth layer) was measured. The wood was macerated as above, and the lengths of 50 randomly selected fibres were measured for each sprout.

Such a sampling technique necessarily involved taking sections at slightly 
different heights, depending on the total height of the sprout. In no case, however, was this difference greater than 30 inches. Furthermore, other workers $(3,10)$ have found that height does not affect the length of fibres obtained from annual rings close to the pith.

\section{RESULtS}

The results of fibre length measurements taken on the fast- and slow-grown trees are presented in Table 2. Each figure represents the average of 10 measurements. At all comparable age levels, the fast-grown trees generally had the longer fibres. These data were subjected to an analysis of variance which is summarized in Table 3. As expected, age from the pith had a significant effect on fibre length. In addition, growth rate class proved to be a significant factor influencing fibre length. It is not likely that this observed differ-

TABLE 2

Average Fibre Length in Fast- and Slow-Grown Black Cottonwoods Sampled at Various Heights and Agrs

\begin{tabular}{|c|c|c|c|c|c|c|c|c|c|}
\hline \multirow{2}{*}{$\begin{array}{l}\text { Height in } \\
\text { Stem } \\
\text { (feet) }\end{array}$} & \multirow{2}{*}{$\begin{array}{c}\text { Age from } \\
\text { Pith } \\
\text { (years) }\end{array}$} & \multicolumn{4}{|c|}{ Slow Grown } & \multicolumn{4}{|c|}{ Fast Grown } \\
\hline & & $\begin{array}{c}\text { Tree } 1 \\
\text { mm. }\end{array}$ & $\begin{array}{c}\text { Tree } 2 \\
\text { mm. }\end{array}$ & $\begin{array}{c}\text { Tree } 3 \\
\text { mm. }\end{array}$ & $\begin{array}{c}\text { Tree } 4 \\
\text { mm. }\end{array}$ & $\begin{array}{c}\text { Tree } 5 \\
\text { mm. }\end{array}$ & $\begin{array}{c}\text { Tree } 6 \\
\text { mm. }\end{array}$ & $\begin{array}{l}\text { Tree } 7 \\
\text { mm. }\end{array}$ & $\begin{array}{c}\text { Tree } 8 \\
\text { mm. }\end{array}$ \\
\hline \multirow[t]{4}{*}{4.5} & 2 & 0.52 & 0.63 & 0.52 & 0.81 & 0.76 & 0.82 & 0.76 & 0.65 \\
\hline & 5 & 0.81 & 0.80 & 0.71 & 0.80 & 1.07 & 1.00 & 1.02 & 0.91 \\
\hline & 10 & 0.93 & 0.87 & 1.02 & 1.00 & 1.14 & 1.25 & 1.35 & 1.08 \\
\hline & 15 & 1.06 & 1.15 & 0.97 & 1.10 & 1.31 & 1.44 & 1.36 & 1.30 \\
\hline \multirow[t]{4}{*}{18} & 2 & 0.57 & 0.62 & 0.50 & 0.57 & 0.67 & 0.72 & 0.68 & 0.81 \\
\hline & 5 & 0.78 & 0.76 & 0.63 & 0.63 & 0.87 & 0.89 & 0.88 & 1.09 \\
\hline & 10 & 0.86 & 1.02 & 0.82 & 0.80 & 1.08 & 1.25 & 1.06 & 1.10 \\
\hline & 15 & 1.06 & 1.10 & 1.01 & 0.93 & 1.45 & 1.44 & 1.16 & 1.45 \\
\hline \multirow[t]{4}{*}{36} & 2 & 0.53 & 0.65 & 0.52 & 0.69 & 0.84 & 0.69 & 0.66 & 0.66 \\
\hline & 5 & 0.85 & 0.95 & 0.74 & 0.79 & 0.96 & 0.93 & 1.05 & 0.94 \\
\hline & 10 & 0.90 & 0.97 & 0.94 & 0.88 & 1.31 & 1.19 & 1.11 & 1.19 \\
\hline & 15 & 1.09 & 1.16 & 1.18 & 1.10 & 1.31 & 1.40 & 1.16 & 1.34 \\
\hline
\end{tabular}

TABLE 3

Analysis of Variance of Fibre Length as Affected by Age, HEIGHT AND GRowth Rate

\begin{tabular}{lcccc}
\hline Source of Variation & D.F. & S.S. & M.S. & F \\
\hline Age & $\mathbf{3}$ & 4.010 & 1.337 & $19.10^{*}$ \\
Height in Stem & 2 & 0.050 & 0.025 & 0.50 \\
Growth Rate & $\mathbf{1}$ & 1.097 & 1.097 & $15.70^{*}$ \\
AxH & 6 & 0.020 & 0.003 & 0.15 \\
AxG & 3 & 0.070 & 0.023 & 0.33 \\
HxG & 2 & 0.021 & 0.010 & $\mathbf{0 . 4 8}$ \\
Error & $\mathbf{7 8}$ & 0.548 & 0.070 & \\
\hline
\end{tabular}

tSignificant at the $0.1 \%$ level. 
ence was due to genetic factors alone, since two of the fast-grown trees came from the same immediate locality as the slow-grown ones and yet had significantly longer fibres.

The results of the measurements taken on sprout material from four stumps are presented graphically in Fig. 1. The data for each individual tree assume a straight line relationship of positive slope; i.e., the wider the 1955 annual ring, the longer the fibre produced. These results, therefore, concur with those obtained on the fast- and slow-growth trees.

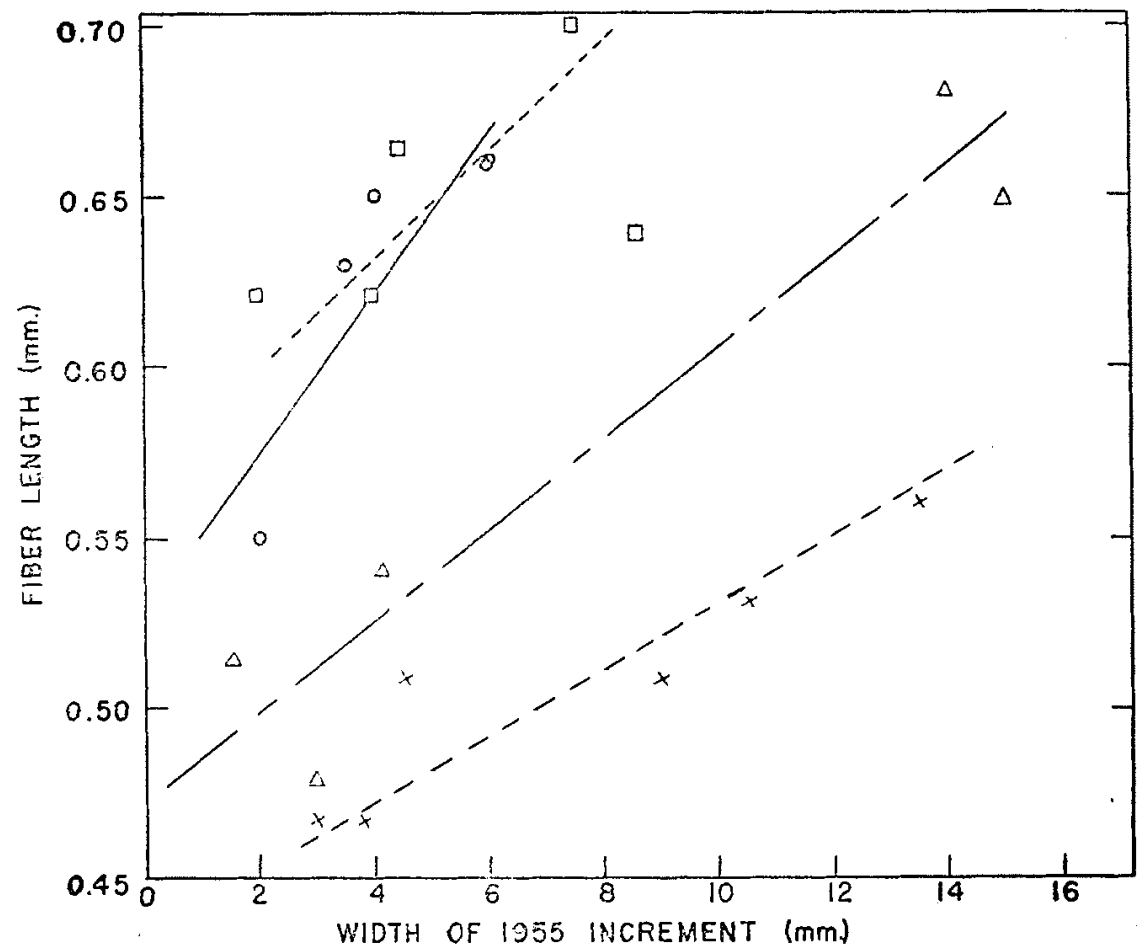

FIGURE 1. Relation between Fibre Length and Radial Growth of Sprouts from Four Black Cottonwood Stumps.

\section{DISCUSSION AND CONCLUSIONS}

Chalk et al (7) have discussed the two factors that can cause variation in fibre length. The first of these factors is length of the initiating cell in the cambium. Bailey (2) has shown that the circumference of woody stems with non-storeyed elements is increased by transverse anticlinal divisions of the cambial initials, followed by elongation and readjustment of the resulting cells. It is evident that cambial initials in fast-grown trees must divide rapidly in this manner to keep pace with the rapid rate of circumferential growth. Therefore, when a tree is increasing rapidly in diameter, the average length of daughter cells produccd by the cambium might be expected to shorten, due 
to the fact that a large number of cambial initials have divided anticlinally. Similarly, a tree growing slowly in diameter would not increase in circumference at a rapid rate, and as a result, fewer cambial cells would need to divide anticlinally. Such a tree could be expected to have fibres of greater length, since cambial initials on the whole, remain long. Evidence to support these ideas has been presented by certain Australian workers $(1,5)$.

The second factor influencing fibre length is that of elongation of the young daughter cells after being cut off by the cambium. This factor is relatively unimportant in conifers, since tracheids lengthen not more than ten per cent during differentiation (2). The length of the cambial initials is of primary importance in controlling tracheid length in conifers. A different pattern is evident in the angiosperms, where post-cambial elongations of as much as 400 per cent are not uncommon (6). Therefore, fibre length may be determined to a large extent by the amount of elongation during differentiation. If this theory is correct, fibre length in a hardwood species will be largely independent of the effect that growth rate might have on regulating the size of cambial initials.

The results of this study indicate that a fast rate of growth does not have a deleterious effect on length of fibre. In contrast, there is positive evidence to indicate that the fast-growing trees produce longer fibres. It appears that in the material investigated, the effect of growth rate on shortening the cambial initials has been overshadowed by the subsequently greater elongation of the daughter cells in the fast-growing trees.

\section{ACKNOWLEDGMENT}

The assistance of Dr. J. H. G. Smith, Assistant Professor, Faculty of Forestry, in collecting samples for this study is gratefully acknowledged. Dr. Smith also provided useful statistical aid.

\section{REFERENCES}

1. AMOS, G. L., I. J. W. BISSET and H. E. DADSWELL. 1950. Wood structure in relation to growth in Eucalyptus gigantea Hook. F. Australia Div. of For. Prod. Rept. No. 130.

2. BAILEY, I. W. 1954. Contributions to plant anatomy. Chronica Botanica Co., Waltham, Mass.

3. BISSET, I. J. W. and H. E. DADSWELL. 1949. The variation of fibre length within one tree of Eucalyptus regnans, F. v. m. Australia Div. of For. Prod. Rept. No. 125.

4. BISSET, I. J. W. and H. E. DADSWELL. 1950. The variation in cell length within one growth ring of certain angiosperns and gymnosperms. Australin Div. of For. Prod. Rept. No. 132.

5. BISSET, I. J. W., H. E. DADSWELL and A. B. WARDROP. 1951. Factors influeacing tracheid length in conifer stems. Australia Div. of For. Prod. Repr. No. 145.

6. BROWN, H. P., A. J. PANSHIN and C. C. FORSAITH. 1949. Textbook of rood technology. Vol. I. McGraw-Hill Book Co., New York.

7. CHALK, L., E. B. MARSTRAND and J. P. DeC. WALSH. 1955, Fibre length in storeyed hardwoods. Acta Botanica Neerlandica, 4: 339-347.

8. KAEISER, MARGARET. 1956. Variations in fibre length of eastern cottonwood. U.S. For. Prod. Lab. Rept. No. 2047

9. SPURR, S. H. and M. J. HYVARINEN. 1954. Wood fibre length as related to position in tree and growth. Bot. Rev., 20: 561-575.

10. STEPHENSON, J. N. 1950. Pulp and paper manufacture. Vol. I. McGraw-Hill Book Co., New York.

11. WILSON, J. W. 1954. Fibre technology I. Fibre length mensuration, a comprehensive history and new method. Pulp and Paper Mag. Can. 55: 84-91. 